\title{
Effectiveness of Blended Learning in English Speaking Skill for Undergraduate in $\mathbf{4 . 0}$
}

\author{
Desvita SARI, Rudy SOFYAN, Ely Hayati NASUTION \\ University of Sumatera Utara, Medan, Sumatera Utara, Indonesia \\ desvitasari9@gmail.com \\ University of Sumatera Utara, Medan, Sumatera Utara, Indonesia \\ rudy@usu.ac.id \\ University of Sumatera Utara, Medan, Sumatera Utara, Indonesia \\ ely@usu.ac.id
}

\begin{abstract}
This research deals with the students' achievement of speaking skills and perception towards Implementing Individual Rotation of blended learning. The writers discuss the effectiveness of blended learning implemented in the pre-test and post-test of English speaking skill achievement of the 2nd semester of English Department students of the University of Sumatera Utara and their perception of it. This research aims to find out how the Individual Rotation Model of blended learning improves students' English speaking skill achievement using the Learn Social platform and to find out students' perceptions after implementing blended learning. In conducting this research, the writers apply descriptive with a mixed-method (Creswell \& Plano Clark, 2011) analyzing the students' achievement found in the pre-test and post-test and giving the online questionnaire to assess their perception towards blended learning. The data shows that the student's achievement in the post-test $($ Mean $=87 \%)$ was higher than the pre-test $($ Mean $=85 \%)$ out of 50 students. According to the data, $90 \%$ of the 42 students gave a positive response to blended learning. The result showed Individual Rotation Model improves the English speaking skill achievement especially in the components of speaking skill namely, vocabulary, grammar, and comprehension, and effective to be implemented for undergraduate students in the era of industrial revolution 4.0.
\end{abstract}

Keywords: blended learning, effectiveness, individual rotation model, industrial revolution 4.0, speaking skill 


\title{
Efektifitas Pembelajaran Campuran Dalam Keterampilan Berbicara Bahasa Inggris Untuk Mahasiswa di 4.0
}

\begin{abstract}
Abstrak
Penelitian ini berkaitan dengan prestasi siswa dalam keterampilan berbicara dan persepsi terhadap penerapan Individual Rotation Model dari blended learning. Para penulis mendiskusikan keefektifan blended learning yang diterapkan dalam tes awal dan tes akhir pencapaian ketrampilan berbahasa Inggris mahasiswa semester 2 Jurusan Bahasa Inggris Universitas Sumatera Utara dan persepsi mereka tentang hal itu. Penelitian ini bertujuan untuk mengetahui bagaimana Individual Rotation Model dari blended learning meningkatkan pencapaian keterampilan berbahasa Inggris siswa menggunakan platform Learn Social dan untuk mengetahui persepsi siswa setelah menerapkan blended learning. Dalam melakukan penelitian ini, penulis menerapkan deskriptif dengan metode campuran, menganalisis prestasi siswa yang ditemukan dalam pre-test dan post-test dan memberikan kuesioner online untuk menilai persepsi mereka terhadap blended learning. Data menunjukkan bahwa prestasi siswa dalam tes akhir $($ Mean $=87 \%$ ) lebih tinggi daripada tes awal (Mean = 85\%) dari 50 siswa. Sementara itu, persepsi mereka tentang blended learning menunjukkan bahwa $90 \%$ dari 42 siswa merespons positif. Hasilnya benar-benar menunjukkan Individual Rotation Model meningkatkan pencapaian keterampilan berbahasa Inggris terutama dalam komponen keterampilan berbicara yaitu, kosa kata, tata bahasa, dan pemahaman dan efektif untuk diterapkan bagi mahasiswa sarjana di era revolusi industri 4.0.
\end{abstract}

Kata kunci: efektivitas, blended learning, individual rotation model, keterampilan berbicara bahasa inggris, revolusi industri 4.0

\section{INTRODUCTION}

Nowadays, the world has been transformed by technology. The spreading of this technology trend is massive and sustainable. People can see the different trends year by year impacted by technology which creates different opportunities and challenges in every sector. For example, the internet, cloud computing, Internet of Things (IoT), Artificial Intelligent (AI), and social media create different opportunities and challenges in every sector. Technology appears and spreads the trend of language in which mostly uses English. For instance, in an educational system, there are significant changes in learning and teaching ways of using technology. Consequently, many questions are argued by the students about how the destiny they face is no longer the same as what their parents experienced, especially for being employed. The technology powered by artificial intelligence defining that the world at present needs more new jobs which never 
appear in the past. The speed and breadth of the current period bring challenges from the aforementioned megatrends (internet, cloud computing, and social media) and the fourth industrial revolution for higher education (Xing \& Marwala, 2017) Therefore, it is important for nations especially Indonesians understand the impact of these changes on all aspects of our lives including higher education. These all have been discussed in the fourth industrial revolution (Industry 4.0) era.

Higher education institutions around the world keep in remaining the same core mission of its fundamental function in whatever era. The aim of higher education is to ensure the quality of learning through teaching, to enable students to get the latest knowledge through exploratory research, and to maintain community development through services (Xing \& Marwala, 2017)). Today's students known as 'digital natives' hope to integrate technology into their learning environment because it gives them the opportunity to expand their learning outside the classroom and become independent students(Qindah, 2018). Meanwhile, it also challenges the lecturers. They have to solve important problems related to the adaptation of the learning process against students' needs, preferences, and requirements that they may not know. The importance of being able to use technology is also proved by the research about online resource management. As technology develops, the use of online resources is more preferable for its efficiency, effectiveness, and practicality (Sofyan \& Tarigan, 2017) This shows that nowadays, in teaching and learning integrated by technology, students and lecturers should be able to use such online resources. Using different teaching methods and approaches is necessary. It can make the students more active in participating. They will have strong motivation and engagement in their own learning process.

A lecturer has the main objective to let students acquire the conceptual knowledge which is applied to many subjects as well as gain an understanding of the particular material and apply it (Xing \& Marwala, 2017) To address this issue, there is blended learning (or called as mixed e-learning) which may contribute a face-to-face learning methodology as a formal education program in which a student learns; at least in part through online delivery of content and instruction, with some element of student control over time, place, path, and/or pace; at least in part in a supervised brick-and-mortar (classroom) location away from home, and the modalities along each student's learning path within a course or subject are connected to provide an integrated learning experience (Christensen, Horn, \& Staker, 2013) 
Figure 1. Blended Learning According to Christiansen, Horn, and Staker (2013)

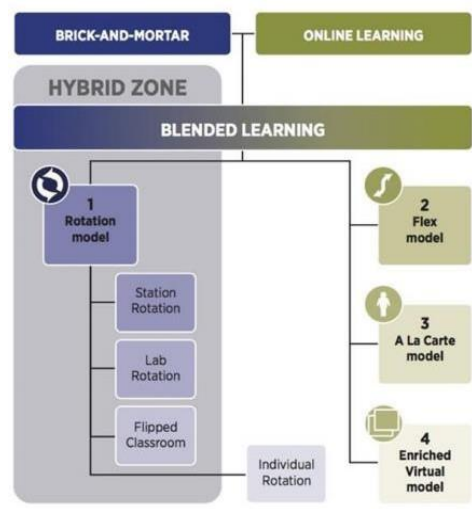

Figure 2. School, and Middle School According to Christiansen, Horn, and Staker (2013)

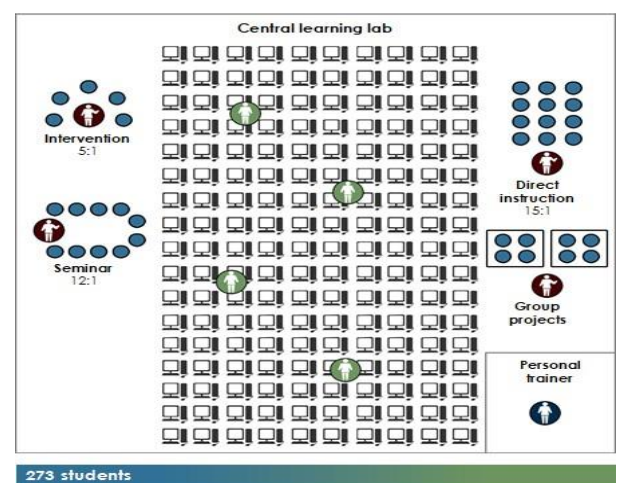

Through this blended learning, a great educational value can be offered by virtual environments in the process of sending information and interactive participation both in real-time such as video conferences and non-simultaneously participant involvement such as forums and chats. At this stage, lecturers can get physical feedback about the effectiveness of transmitting their knowledge to students. Then to find out an understanding of certain conceptual problems, it lets the lecturer further assess and reinforce through online graph representation and multiple-choice test questions. In addition, this offers students the advantage of reviewing their results immediately (Xing \& Marwala, 2017).

As in the middle of this period, it should be a learning method to consider that the higher education system needs to see how they can accept that technologies have spread in the students' daily life. Changing the learning and teaching environment for the benefit of students and academics is better than fighting these modern technologies. Portrayed in the phenomenon of nowadays, there are so many students who study 
English as a foreign language (EFL). They can understand English when they listen or read, but they find so many difficulties to speak or write in English. In other words, they have passive English.

The fact that EFL students are expected to have good communication skills in English but still lack grammar especially in speaking, listening and writing is also proved by the previous study done by Suzan Qindah (Qindah, 2018) She emphasizes that from her experience as a teacher most students learn the rules of grammar and memorize them. So when presenting a topic, either spoken or written, they still cannot apply the grammar they have learned in context. Learning grammar in different contexts and also practicing it is certainly needed interactively. Blended learning is suitable to be applied in courses related to English grammar, especially speaking which indeed shows the usefulness of massive grammar for EFL students (Isti'anah, 2017). The activities given online are proven to help the students exercise their understanding of the given materials, seen from the results in both pre-test and post-test. Therefore, in this study, the writer is interested to focus on the effectiveness of blended learning in English language skills for undergraduate students in the era of Industry 4.0. This study will investigate whether it is possible to integrate technology in learning speaking skills.

This study aims to examine the effectiveness of blended learning especially the Individual Rotation model in English Speaking skills for undergraduate students, majoring in English Literature at the University of Sumatera Utara during the second semester of the scholastic year 2018-2019. Constantly, it also relevant to what this university needed is. According to Silvana Sinar (Sinar, 2019) in the book 'Pemikiran Guru Besar USU "Pendidikan Tinggi di Era Revolusi Industri 4.0" entitled 'Peran Dosen USU Dalam Menghadapi Pembelajaran di Era Revolusi Industri 4.0' as one of the professors of University of Sumatera Utara, she said that most of the lecturers at the University of Sumatera Utara are digital immigrants who will have difficulty in preparing e-learning (Sofyan \& Tarigan, 2017).

There are seven types of blended learning models, namely, the Rotation model consists of Station Rotation model, Lab Rotation model, Individual Rotation model, Flipped classroom model, Flex model, A La Carte model, and Enriched Virtual model. In this case, the writer only focused on analyzing how the Individual Rotation Model (IRM) functions as an effective way to improve the students' English-speaking skill achievement which focused on the components of speaking skill namely comprehension, grammar, vocabulary, pronunciation, and fluency according to Harris; 1974 (Kurniati, Eliwarti \& Novitri, 2015) in speaking subject of the second semester of English Department of University of Sumatera Utara year 2018-2019 
Subsequently, the effectiveness of the Individual Rotation model was analyzed based on the achievement and perception of the students after being implemented the IRM. The treatment of the IRM uses a platform named the Learn Social by the Language Centre, University of Sumatera Utara. The students' English achievement was tested by pre-test and post-test using the Learn Social platform itself. In addition, the questionnaire for knowing the perception of students was designed by Shortened Experiences of Teaching and Learning Questionnaire (SETLQ) and analyzed by the Likert Scale.

This study is needed because English students are expected to have good English skills after graduating especially speaking skills. Due to a native speaker is the speaker of a language, not a reader or writer that is why they would be said as speakers of language if they can speak it fluently. Therefore speaking skill is most required. This analysis illustrates whether there are effects on the improvement of students' English achievement in speaking subject after applying the Individual Rotation model using the Learn Social platform especially in this Industry 4.0. Then, this study illustrates the perceptions of the student about blended learning. Finally, blended learning is expected to be effective to be applied, to facilitate, and to improve the achievement of students in the English language, so University of Sumatera Utara students will get the benefits from it especially in this present Industry 4.0.

\section{METHOD}

In conducting this research, the writers chose the first-year (2018) students as the subjects. The population was the active students in the second semester of the Department of English, University of Sumatera Utara, exactly the academic year of 2018/2019. The sample was class A (62 students). The sample is studying speaking subjects using the LMS (Learning Management System) platform named the Learn Social by the Language Centre, University of Sumatera Utara. In the process of conducting the research, the writers found problems in contacting the students. Despite the things that happened, the writers then took that as a rejection and focus on analyzing the rest of the subjects, where there were 50 students for the achievement test and 42 students for the perception questionnaire in total. 
Figure 3. the Learn Social Platform

by Language Centre University of Sumatera Utara
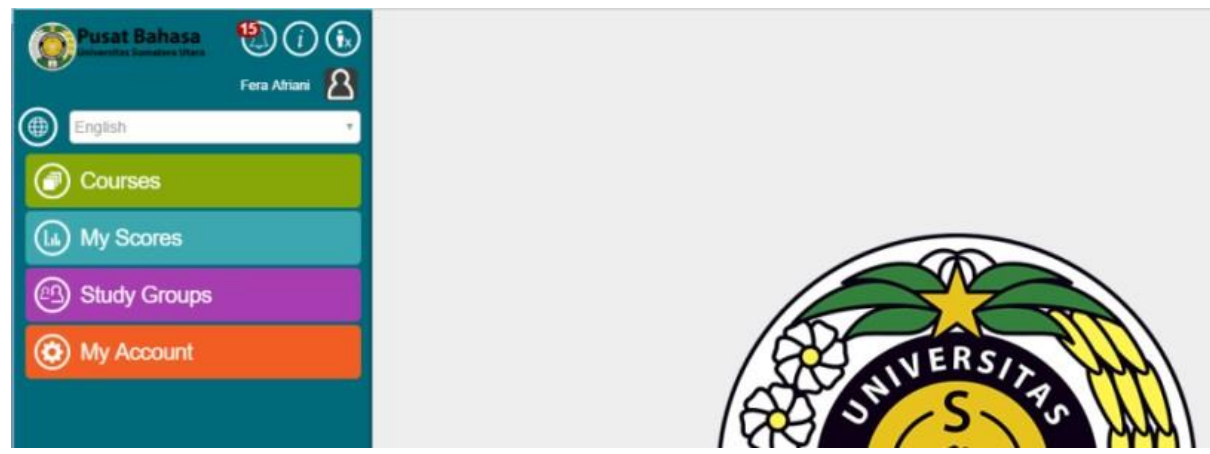

An English test was used as one of the instruments to collect the data for students' English achievement. The English test was conducted before and after the treatment. The treatment of the IRM uses the Learn Social platform or LMS as the online teaching and learning media to the sample. The students were asked to do the tests in the basic competency of General English Subscription (GES): Connected General English both indirect interaction and through communication tools. Then, the pre-test and post-test were conducted by using the Learn Social platform in order to see the significant improvement after using the IRM.

A twenty five-items questionnaire of students' perception designed by Shortened Experiences of Teaching and Learning Questionnaire (SETLQ) from ETL Project to know the students' perception after applying the IRM. It was constructed on Google Forms in order to ensure that the student can fill it everywhere but still in or on time of the deadline. For most of the items in the questionnaire, students responded on a 1 - 5 scale ( $5=$ high). The score of experiences of teaching and learning scale is agree $=5$, agree somewhat $=4$, unsure $=3$, disagree somewhat $=2$, disagree $=1$. It was analyzed by the Likert Scale.

In conducting this research, the students have been taught English skills by their lecturer. However, during the study, the students were exposed to additional online resources in speaking class. These resources include courses, online worksheets, and quizzes. It meant the researcher used online and offline technological resources. All the students were given treatment by the use of the IRM, that is, the use of classroom learning and online learning through the internet, namely the Learn Social platform. Then, in applying the assessment, the researcher used the same platform in a particular part namely Level Test in the Learn Social. While for the questionnaire, it was conducted by using the Google Forms platform. The research procedures of this study are explained as follows; a. The sample of this research is determined by using purposive sampling. There are 2 classes (A and B) of the second semester majoring in English Literature 2018 and chose English Literature (A) which consists of 62 students determined to be the 
sample of this research in consideration that they used the Learn Social platform which conducting the IRM in speaking subject and this study should be conducted in the very first year of undergraduate students; $b$. The instrument materials of pre-test and posttest, and also questionnaire chose by the writer. The selecting process considered the materials being taught to the students in the second semester; c. The pre-test and posttest were tried out to the sample in order to find out the result of their English speaking skill achievement by the level test in the Learn Social platform given; d. Administering the pre-test to find the result of the students' English speaking skill achievement; e. Implementing blended learning for the sample. The IRM was being applied to the students; f. Giving the post-test by the Learn Social to the students after implementing blended learning; g. Administering the post-test to find the result of the students' English speaking skill achievement; $h$. Giving the questionnaire to the sample in order to know the students' perceptions after applying the IRM by using Google Forms; i. Administering the result of the questionnaire given to the students; j. Analyzing the data from the instruments.

The output data from the pre-test and post-test were used to find out the significant difference in the progress and contribution before and after the IRM in English speaking skill achievement. Then the output data from the questionnaire was used to find out the perceptions of students after implementing the IRM. Then, after both instruments' data were found, the writer knew whether the IRM is effective to be conducted in the next year and with another subject.

In collecting the data, the technique used was an English test and a questionnaire. To collect the data for the student's achievement, the sample was tested by asking them to do an English test (Level Test) on the basic competency of GES: Connected General English through the Learn Social platform. The test was given in the forms of pre-test and post-test, before and after the treatment.

Furthermore, to collect the data for students' perception of blended learning, the writer used a questionnaire. The items of the questionnaire were constructed based on Shortened Experiences of Teaching and Learning Questionnaire (SETLQ). Then the questionnaire was distributed to the sample of this research to fill in the Google Forms after the treatment of the IRM.

To evaluate students' achievement in English speaking skills, the researcher gave thirty (30) questions of the speaking skill components. They were ten of vocabulary, ten of grammar, and ten of language and use questions in the form of pre-test and post-test. The test was scored automatically by the Learn Social platform. 
Nevertheless, to evaluate the data of students' perception of blended learning, the writer used the Likert Scale on a $1-5$ scale ( $5=$ very high). Which the score of experiences of teaching and learning scale is agree $=5$, agree somewhat $=4$, unsure $=3$, disagree somewhat $=2$, disagree $=1$. The scales chose by the students showed how their perception of this blended learning. Then the result of this questionnaire was a consideration of is it effective to apply blended learning to undergraduate students based on the Indicator of Success(Windi Rahmi Reg, 2017) (see Table 1).

Table 1. Indicator of Success

\begin{tabular}{|c|c|c|c|}
\hline Index (\%) & Assessment Interval & $\begin{array}{c}\text { Numbe } \\
\text { r of } \\
\text { Scales }\end{array}$ & Category \\
\hline $80 \%-100 \%$ & Agree & 5 & Very High \\
\hline $60 \%-79.99 \%$ & Agree Somewhat & 4 & High \\
\hline $40 \%-59.99 \%$ & Unsure & 3 & Average \\
\hline $20 \%-39,99 \%$ & Disagree Somewhat & 2 & Low \\
\hline $0 \%-19,99 \%$ & Disagree & 1 & Very Low \\
\hline
\end{tabular}

Sourced by: Windi Rahmi (2017)

The questionnaire was distributed to the sample of this research and filled in the Google Forms after the treatment of the IRM.

The data was processed by multiplying each answer with a predetermined weight based on a value weight table for each question of the questionnaire. Where:

1. In one question, each scale $=$ (respondents $\mathrm{x}$ scale)

2. Total score $=$ the sum up of the whole score of each scale in one question

3. Maximum Score $=$ (number of respondents $\mathrm{x}$ highest Likert score)

4. Minimum Score $=$ (number of respondents $\mathrm{x}$ lowest Likert score)

5. Index $(\%)=($ Maximum Total Score $/$ Score $) \times 100$

\section{FINDINGS AND DISCUSSION}

This research focused on analyzing the result of English achievement found on the 2nd semester of English Department students of University of Sumatera Utara's and assessed their perception of IRM of blended learning through Shortened Experiences of Teaching and Learning analyzed the Likert scale.

In the process of conducting the research, the writer found problems. The first one is from 62 students there were only 50 students who followed the pre-test and the posttest. The second one is in contacting the students for submitting the questionnaire, almost half of the respondents were not responding due to they are not actively attending lectures. Despite the things that happened, the writer then took that as a rejection and focused on analyzing the other half of the respondents, there were 42 students in total for the questionnaire. 
In this section, there are two parts the writer would like to analyze each of the data gathered from the IRM research activities. The results were written in qualitative and quantitative data. The data was achieved from the teaching and learning processes including English speaking skills in the form of online level tests. The aim of giving the test was to know the students' achievement mastering the English speaking skill given in this research in a specific percentage. The analysis started from pre-test up to post-test and questionnaire.

To find out the comparison of the students' achievement from pre-test up to posttest, the score and the mean of each student score were tabulated automatically by the platform, and the score from the students judged by the indicator of success to know the effectiveness.

The pre-test was conducted at the beginning of the research. The purpose of this test was to check the achievement of the students before doing the implementation of IRM by the Learn Social platform. The pre-test was conducted on April 8-12, 2019. There were 50 students who followed this test which they were supposed to be 62 students in Class A 2018 because the rest were not filled the whole test at the proper time.

In the pre-test, the students should do Vocabulary, Grammar, and Language \& Use tests of the Learn Social platform. The topics were chosen due to the platform is using the GES: Connected General English e-book. The average score of the pre-test was 85\%. It did not show a significantly low score and was even classified as good. This is based on the results of the analysis of the pre-test scores of students in A1 Beginner material indicating that there was no difficulty for students to answer from the average pre-test value. In addition, the percentage of their completeness has also reached more than $75 \%$. So that it can be said that they are kind of having good English skills as second semester English Department students. The result of this pre-test is in the table (see Table 2).

Table 2. Result of the Pre-test

\begin{tabular}{|r|l|r|r|r|r|r|}
\hline & & \multicolumn{3}{|c|}{ Pre-test } & \multicolumn{2}{c|}{ Total } \\
\cline { 3 - 8 } No. & $\begin{array}{l}\text { Student's } \\
\text { Code }\end{array}$ & $\begin{array}{c}\text { Vocabul } \\
\text { ary } \\
(\mathbf{1 0 )}\end{array}$ & $\begin{array}{c}\text { Grammar } \\
\mathbf{( 1 0 )}\end{array}$ & $\begin{array}{c}\text { Language } \\
\text { and Use } \\
(\mathbf{1 0 )}\end{array}$ & $\begin{array}{c}\text { Score } \\
\text { (Max=30) }\end{array}$ & \multicolumn{1}{c|}{$\begin{array}{c}\text { Index } \\
\text { (\%) }\end{array}$} \\
\hline 1 & AN & 6 & 4 & 9 & 19 & 63.3 \\
\hline 2 & AF & 7 & 7 & 9 & 23 & 76.7 \\
\hline 3 & ANA & 7 & 6 & 8 & 21 & 70 \\
\hline 4 & ANP & 7 & 9 & 9 & 25 & 83.3 \\
\hline 5 & AD & 9 & 7 & 10 & 26 & 86.7 \\
\hline 6 & AM & 7 & 10 & 10 & 27 & 90 \\
\hline 7 & AT & 8 & 5 & 10 & 23 & 76.7 \\
\hline
\end{tabular}




\begin{tabular}{|c|c|c|c|c|c|c|}
\hline 8 & $\mathrm{BM}$ & 8 & 5 & 7 & 20 & 66.7 \\
\hline 9 & $\mathrm{CP}$ & 6 & 7 & 10 & 23 & 76.7 \\
\hline 10 & $\mathrm{CTF}$ & 8 & 7 & 8 & 23 & 76.7 \\
\hline 11 & DA & 5 & 3 & 6 & 14 & 46.7 \\
\hline 12 & DRY & 9 & 8 & 10 & 27 & 90 \\
\hline 13 & $\mathrm{DS}$ & 6 & 5 & 9 & 20 & 66.7 \\
\hline 14 & $\mathrm{DM}$ & 7 & 7 & 9 & 23 & 76.7 \\
\hline 15 & $\mathrm{EV}$ & 8 & 6 & 9 & 23 & 76.7 \\
\hline 16 & EKB & 8 & 6 & 9 & 23 & 76.7 \\
\hline 17 & IS & 6 & 6 & 10 & 22 & 73.3 \\
\hline 18 & $\mathrm{JZ}$ & 9 & 10 & 10 & 29 & 96.7 \\
\hline 19 & $\mathrm{KH}$ & 10 & 10 & 10 & 30 & 100 \\
\hline 20 & KYS & 8 & 7 & 9 & 24 & 80 \\
\hline 21 & $\mathrm{LJ}$ & 9 & 5 & 7 & 21 & 70 \\
\hline 22 & MA & 10 & 10 & 10 & 30 & 100 \\
\hline 23 & MP & 10 & 10 & 10 & 30 & 100 \\
\hline 24 & MPS & 10 & 7 & 10 & 27 & 90 \\
\hline 25 & MRA & 7 & 7 & 8 & 22 & 73.3 \\
\hline 26 & MRA & 7 & 6 & 9 & 22 & 73.3 \\
\hline 27 & MRR & 7 & 7 & 8 & 22 & 73.3 \\
\hline 28 & NK & 8 & 6 & 10 & 24 & 80 \\
\hline 29 & $\mathrm{NS}$ & 8 & 8 & 8 & 24 & 80 \\
\hline 30 & NSR & 8 & 6 & 10 & 24 & 80 \\
\hline 31 & PAS & 10 & 7 & 8 & 25 & 83.3 \\
\hline 32 & RRDB & 8 & 10 & 10 & 28 & 93.3 \\
\hline 33 & RDA & 7 & 5 & 9 & 21 & 70 \\
\hline 34 & RST & 5 & 4 & 10 & 19 & 63.3 \\
\hline 35 & $\mathrm{RR}$ & 9 & 8 & 10 & 27 & 90 \\
\hline 36 & REZ & 9 & 8 & 10 & 27 & 90 \\
\hline 37 & $\mathrm{RN}$ & 7 & 6 & 9 & 22 & 73.3 \\
\hline 38 & RA & 6 & 4 & 9 & 19 & 63.3 \\
\hline 39 & RA & 6 & 9 & 9 & 24 & 80 \\
\hline 40 & SR & 8 & 7 & 9 & 24 & 80 \\
\hline 41 & SS & 8 & 8 & 9 & 25 & 83.3 \\
\hline 42 & $\mathrm{SF}$ & 10 & 9 & 9 & 28 & 93.3 \\
\hline 43 & SK & 8 & 10 & 10 & 28 & 93.3 \\
\hline 44 & SAR & 10 & 9 & 10 & 29 & 96.7 \\
\hline 45 & SNBB & 7 & 6 & 10 & 23 & 76.7 \\
\hline 46 & SBS & 9 & 8 & 10 & 27 & 90 \\
\hline 47 & TB & 9 & 8 & 10 & 27 & 90 \\
\hline 48 & TFA & 7 & 8 & 9 & 24 & 80 \\
\hline 49 & WM & 7 & 7 & 9 & 23 & 76.7 \\
\hline 50 & ZA & 8 & 7 & 10 & 25 & 83.3 \\
\hline
\end{tabular}




\begin{tabular}{|r|r|}
\hline Total & 1700 \\
\hline Mean & 85 \\
\hline
\end{tabular}

Based on the data above, the mean achievement of the post-test was $87 \%$. It was higher than the previous result which was $85 \%$ even though it was not the significantly massive of growth yet it was an improvement. These results led the writer to conclude that the IRM of blended learning could help the students to achieve a better result in learning and mastering English speaking skills. It can be concluded that the student's achievement in learning English speaking skills by implementing the IRM using Learn Social had good improvement.

After the implementation of the IRM had been finished, the student's English speaking skill was evaluated by giving a post-test. It was conducted on June 22-26, 2019 on the Learn Social platform. In the post-test, there were 30 item-questions of B1 Preintermediate that were quite similar to the pre-test. The writer was helped by the lecture. The result of the students' achievement in the post-test can be seen in the table (see Table 3).

Table 3. Result of the Post-test

\begin{tabular}{|c|c|c|c|c|c|c|}
\hline \multirow[b]{2}{*}{ No. } & \multirow[b]{2}{*}{$\begin{array}{l}\text { Student's } \\
\text { Code }\end{array}$} & \multicolumn{3}{|c|}{ Post-test } & \multicolumn{2}{|c|}{ Total } \\
\hline & & $\begin{array}{c}\text { Vocabulary } \\
\text { (10) }\end{array}$ & $\begin{array}{l}\text { Grammar } \\
\text { (10) }\end{array}$ & $\begin{array}{l}\text { Language } \\
\text { and Use } \\
\text { (10) }\end{array}$ & \begin{tabular}{l}
\multicolumn{1}{c}{ Sco } \\
re \\
(Max= \\
$30)$
\end{tabular} & Index (\%) \\
\hline 1 & AN & 4 & 8 & 9 & 21 & 70 \\
\hline 2 & $\mathrm{AF}$ & 8 & 6 & 10 & 24 & 80 \\
\hline 3 & ANA & 7 & 7 & 10 & 24 & 80 \\
\hline 4 & ANP & 8 & 8 & 10 & 26 & 86.7 \\
\hline 5 & $\mathrm{AD}$ & 10 & 10 & 9 & 29 & 96.7 \\
\hline 6 & $\mathrm{AM}$ & 10 & 9 & 9 & 28 & 93.3 \\
\hline 7 & AT & 8 & 7 & 9 & 24 & 80 \\
\hline 8 & $\mathrm{BM}$ & 5 & 6 & 10 & 21 & 70 \\
\hline 9 & $\mathrm{CP}$ & 8 & 6 & 9 & 23 & 76.7 \\
\hline 10 & CTF & 6 & 8 & 9 & 23 & 76.7 \\
\hline 11 & DA & 6 & 8 & 7 & 21 & 70 \\
\hline 12 & DRY & 10 & 9 & 10 & 29 & 96.7 \\
\hline 13 & $\mathrm{DS}$ & 8 & 7 & 9 & 24 & 80 \\
\hline 14 & $\mathrm{DM}$ & 9 & 7 & 8 & 24 & 80 \\
\hline 15 & $\mathrm{EV}$ & 8 & 7 & 10 & 25 & 83.3 \\
\hline 16 & EKB & 8 & 7 & 10 & 25 & 83.3 \\
\hline 17 & IS & 8 & 6 & 10 & 24 & 80 \\
\hline 18 & $\mathrm{JZ}$ & 9 & 10 & 10 & 29 & 96.7 \\
\hline 19 & $\mathrm{KH}$ & 10 & 10 & 10 & 30 & 100 \\
\hline
\end{tabular}




\begin{tabular}{|c|c|c|c|c|c|c|}
\hline 20 & KYS & 8 & 8 & 9 & 25 & 83.3 \\
\hline 21 & $\mathrm{LJ}$ & 8 & 10 & 10 & 28 & 93.3 \\
\hline 22 & MA & 10 & 10 & 10 & 30 & 100 \\
\hline 23 & MP & 10 & 10 & 10 & 30 & 100 \\
\hline 24 & MPS & 10 & 10 & 9 & 29 & 96.7 \\
\hline 25 & MRA & 8 & 7 & 9 & 24 & 80 \\
\hline 26 & MRA & 8 & 8 & 9 & 25 & 83.3 \\
\hline 27 & MRR & 10 & 9 & 9 & 28 & 93.3 \\
\hline 28 & NK & 10 & 9 & 9 & 28 & 93.3 \\
\hline 29 & NS & 10 & 10 & 9 & 29 & 96.7 \\
\hline 30 & NSR & 10 & 10 & 10 & 30 & 100 \\
\hline 31 & PAS & 9 & 9 & 9 & 27 & 90 \\
\hline 32 & RRDB & 10 & 9 & 10 & 29 & 96.7 \\
\hline 33 & RDA & 8 & 8 & 10 & 26 & 86.7 \\
\hline 34 & RST & 8 & 6 & 9 & 23 & 76.7 \\
\hline 35 & $\mathrm{RR}$ & 9 & 8 & 10 & 27 & 90 \\
\hline 36 & REZ & 10 & 9 & 10 & 29 & 96.7 \\
\hline 37 & $\mathrm{RN}$ & 9 & 7 & 9 & 25 & 83.3 \\
\hline 38 & $\mathrm{RA}$ & 9 & 6 & 7 & 22 & 73.3 \\
\hline 39 & RA & 8 & 9 & 10 & 27 & 90 \\
\hline 40 & SR & 8 & 9 & 9 & 26 & 86.7 \\
\hline 41 & SS & 9 & 7 & 10 & 26 & 86.7 \\
\hline 42 & $\mathrm{SF}$ & 10 & 10 & 10 & 30 & 100 \\
\hline 43 & SK & 10 & 9 & 10 & 29 & 96.7 \\
\hline 44 & SAR & 10 & 10 & 10 & 30 & 100 \\
\hline 45 & SNBB & 9 & 5 & 9 & 23 & 76.7 \\
\hline 46 & SBS & 10 & 9 & 9 & 28 & 93.3 \\
\hline 47 & TB & 10 & 10 & 10 & 30 & 100 \\
\hline 48 & TFA & 10 & 8 & 10 & 28 & 93.3 \\
\hline 49 & WM & 7 & 8 & 8 & 23 & 76.7 \\
\hline \multicolumn{6}{|c|}{ Total } & 1740 \\
\hline \multicolumn{6}{|c|}{ Mean } & 87 \\
\hline
\end{tabular}

The questionnaire was given to the students in order to know how their perceptions towards this kind of learning model. Since they are the students of the English Department, it is a must to have good English achievement. The IRM has been implemented in the students' speaking subjects. It is a good improvement of the English Department to have such modern stuff due to now is the industrial revolution 4.0 which all the world have been transformed by the Internet and will go to the Internet of Things (IoT).

The questionnaire was intended to gain evidence of their perceptions about blended learning. After all students' responses were recorded, they were granted access to the 
online experimental material that consisted of courses of the lecture typically delivered on the topic to be learned. The students had approximately one week to access the online material at their own time and pace. The students experienced these online courses on a web-based platform (Learn Social). The principal investigator/lecturer went over the learning platform before students experienced the first stage of blended learning, so every student understood how the e-learning environment works. After all the students had submitted the online courses, they came to the in-person class and the lecturer addressed all questions that students had about the lecture so they would be better prepared for the ensuing group discussions.

A post-treatment, five-point Likert scale electronic questionnaire was given to the students regarding their perceptions of the blended learning experience. The questionitems in this questionnaire were designed by Shortened Experiences of Teaching and Learning Questionnaire (SETLQ) by ETL Project. There were 25 questions of multiple choices. The respondents who filled the questionnaire were only 42 students from 62 students. The following is the result of how the students experienced perception of the IRM using Learn Social platform. The suggestions came from the students as the limitation of this research and to ensure confidentiality, anonymous individual suggestions were used. The researcher addressed the suggestion (positive and negative feedback) as the items on the Likert survey in order to obtain evidence of validation and triangulation. The data were processed by multiplying each answer with a predetermined weight based on a value weight table for each question of the questionnaire. The result of students' experienced perception of the IRM using the Learn Social platform is on the table (see Table 4).

Table 4. the Results of Perceptions on the IRM of Blended Learning

\begin{tabular}{|c|c|c|c|c|}
\hline \multirow[b]{2}{*}{ No. } & \multirow[b]{2}{*}{$\begin{array}{l}\text { Types of Teaching and } \\
\text { Learning Experience }\end{array}$} & \multirow[b]{2}{*}{$\begin{array}{r}\text { Questionnaire } \\
\text { (Statement) }\end{array}$} & \multicolumn{2}{|c|}{ The Results } \\
\hline & & & $\begin{array}{l}\text { Total } \\
\text { Score }\end{array}$ & Index (\%) \\
\hline 1 & \multirow{5}{*}{ Aims and congruence } & S 1 & 203 & 96.6 \\
\hline 2 & & S 2 & 193 & 91.9 \\
\hline 3 & & S 3 & 198 & 94.2 \\
\hline 4 & & S 4 & 201 & 95.7 \\
\hline 5 & & S 5 & 180 & 85.7 \\
\hline 6 & \multirow{2}{*}{ Choice allowed } & S 6 & 197 & 93.8 \\
\hline 7 & & S 7 & 177 & 84.2 \\
\hline 8 & \multirow{5}{*}{ Teaching for understanding } & S 8 & 198 & 94.2 \\
\hline 9 & & S 9 & 196 & 93.3 \\
\hline 10 & & S 10 & 172 & 81.9 \\
\hline 11 & & S 11 & 186 & 88.5 \\
\hline 12 & & S 12 & 180 & 85.7 \\
\hline 13 & \multirow[b]{3}{*}{ Set work and feedback } & S 13 & 185 & 88.09 \\
\hline 14 & & S 14 & 183 & 87.1 \\
\hline 15 & & S 15 & 198 & 94.2 \\
\hline
\end{tabular}




\begin{tabular}{|c|c|c|c|c|}
\hline 16 & & S 16 & 190 & 90.4 \\
\hline 17 & & S 17 & 189 & 90 \\
\hline 18 & \multirow{2}{*}{ Assessing understanding } & S 18 & 192 & 91.4 \\
\hline 19 & & S 19 & 188 & 89.5 \\
\hline 20 & \multirow{2}{*}{ Staff enthusiasm and support } & S 20 & 181 & 86.1 \\
\hline 21 & & S 21 & 183 & 87.1 \\
\hline 22 & \multirow{2}{*}{ Student support } & S 22 & 172 & 81.9 \\
\hline 23 & & S 23 & 195 & 92.8 \\
\hline 24 & \multirow{2}{*}{ Interest and enjoyment } & S 24 & 192 & 91.4 \\
\hline 25 & & S 25 & 190 & 90.4 \\
\hline & Total & & 4719 & 90 \\
\hline
\end{tabular}

By the data in the table, it concluded that from 42 respondents of English Department students class A (2018), 90\% of the students are positively respond to the implementation of IRM of blended learning by using the Learn Social platform which is included in the very high level with "A" quality.

Having analyzed the pre-test and post-test, collecting the data, and comparing the result of the pre-test to the result of the post-test, the writer got some findings concerned with the implementation of IRM using the Learn Social platform. The writer concluded it with two points. Those are how the IRM improves the students' English speaking skill achievement in speaking subjects using the Learn Social platform and what the students' perceptions are after implementing blended learning. According to the results of the pretest and post-test sessions, there were 50 students out of 62 students who passed all the tests considered as the students who have the improvement in their English speaking skills, while the rest have failed at the pre-test and post-test.

Subsequently, according to the results of the questionnaire session, there were only 42 students out of 62 students of English Department students class A (2018) which $90 \%$ of them positively respond to the implementation of IRM of blended learning by using the Learn Social platform. It can be said that is effective due to it is relevant to the aspects of learning process effectiveness seen in the table (see Table 5).

Table 5. Aspects of Learning Process Effectiveness According to Suryacitra (2018)

\begin{tabular}{|c|c|c|}
\hline No. & Aspects of Effectiveness & $\boldsymbol{X}$ \\
\hline 1 & The teacher has to make a systematic teaching preparation. & $\boldsymbol{V}$ \\
\hline 2 & $\begin{array}{c}\text { The teaching and learning process (learning) must be of } \\
\text { high quality as indicated by the systematic delivery of } \\
\text { material by the teacher, and using various variations in } \\
\text { delivery, be it media, methods, sounds, or } \\
\text { movements. }\end{array}$ & $\boldsymbol{V}$ \\
\hline 3 & $\begin{array}{c}\text { The time during the teaching and learning process takes } \\
\text { place effectively. }\end{array}$ & $\boldsymbol{V}$ \\
\hline 4 & Teacher teaching motivation and student learning \\
motivation are quite high.
\end{tabular}


The educational system grows rapidly because it is important to have and should follow the development of this revolution. Thus, the lecturer or teacher along with the students should be aware of this massive internet of things in order to get the knowledge of teaching and learning go effectively as how computer and internet growing up.

Based on the analysis of the research, it is indeed good for the students in learning English speaking skills through this learning model. It is proven by the total score found in the tests, which means there are most of the students who were familiar with the internet things so that most of them got the high score in the level tests (pre-test and post-test). Even though it is not the whole of the student, yet the number of students who have filled the whole tests of English speaking skill over $1 / 2 n+1$ from 62 students and is well enough to be calculated.

The results of the previous research are conducted by Suryacitra. In her study, learning is said to be effective against learning outcomes if $75 \%$ of students have reached the KKM score, ie 70, and statistically, the post-test scores of students show a significant difference between the post-test scores where the average post-test scores the experimental class is higher than the average score of the post-test control class students. So it can be concluded that the application of the Flipped Classroom learning model is effective in terms of student learning outcomes in Vector material in class $\mathrm{X}$ MIPA SMA 1 Karanganom(Suryacitra, 2018). Comparing to the research conducted by the writer, more or less it has the same result where the implementation of IRM of blended learning is effective in terms of student learning outcomes in speaking subjects. In this case, the writer used the English Department students who use the Learn Social platform.

Another research conducted by Spyridon Varthis entitled 'Students' Perceptions of Blended Learning and its Effectiveness As a Part of Second Year Dental Curriculum' showed that positive responses to the blended learning experience as part of their dental medical education (Varthis, 2016)). For the Likert scale responses to general blended learning items, the responses tended to be in the neutral range initially but increased toward the more positive range of "Agree," after the blended learning experience. For the content achievement test, the results indicating that the blended learning experience was at least as effective in promoting learning content(Jenny White, 2018). Comparing to the research conducted by the writer, more or less it has the same result where the implementation of IRM of blended learning is effective in terms of a student achievement test, the results show an improvement from $85 \%$ up to $87 \%$ even this is not showing 
significant and massive improvement yet the response of the students after doing this IRM showed 90\% of the English Department student is positively response with the more positive range of "Agree" after the blended learning experience.

The difference between this study and previous research is that this research was applied to undergraduate students who are already using online classes today, were first applied at USU (University of Sumatera Utara), and are very useful and relevant to current needs during the Covid 19 pandemic.

\section{CONCLUSION}

Based on the results of research obtained, analysis, and discussion, the writer concludes that the average value of student achievement in the post-test is higher than the average value of student achievement in the pre-test even though it is not too significant because the value of students at the pre-test has entered the good category. So, it can be concluded that the average value of student learning outcomes in English speaking skill on material A1 Beginner to B1 Pre-Intermediate from GES: Connected General English e-book using the IRM improves than the previous. The score of the students in the post-test increased from the score in the pre-test after the students got the treatment. The mean score in the post-test $(\mathrm{M}=87 \%)$ was higher than the mean score in the pre-test $(M=85 \%)$. It was found that the IRM is effective to improve students' English achievement of English skills and the effectiveness of the Individual Rotation model as a method of improving students' achievement of English learning is good.

The result of students' perception who have experienced running IRM is very good because $90 \%$ respond positively. So, it can be concluded that students' perceptions in English speaking skill learning on A1 Beginner to B1 Pre-Intermediate material from GES: Connected General English e-book is very effective and motivates student learning in speaking learning which is often considered difficult for students.

\section{REFERENCES}

Christensen, C. M., Horn, M. B., \& Staker, H. (2013). Is K-12 Blended Learning Disruptive? An Introduction to the Theory of Hybrids.

Creswell, J. W., \& Plano Clark, V. L. (2011). Designing and conducting mixed methods research. SAGE Publications.

Isti'anah, A. (2017). The Effect of Blended Learning to the Students' Achievement in Grammar Class. IJEE (Indonesian Journal of English Education), 4(1), 1630. https://doi.org/10.15408/ijee.v4i1.5697 
Jenny White. (2018, March 6). How to Customize Learning With Individual Rotation.

Qindah, S. (2018). The Eurasia Proceedings of Educational \& Social Sciences (EPESS) The Eurasia Proceedings of Educational The Effects of Blended Learning on EFL Students' Usage of Grammar in Context. \& Social Sciences (EPESS), 10. Retrieved from www.isres.org

Sinar, T. S. (2019). Peran dosen USU dalam menghadapi pembelajaran era revolusi industry 4.0. Medan: USU Press.

Sofyan, R., \& Tarigan, B. (2017). Online Resources Management in SelfCorrections and Translation Quality. International Journal of Sciences: Basic and Applied Research (IJSBAR) International Journal of Sciences: Basic and Applied Research, 35(2), 212-224. Retrieved from http://gssrr.org/index.php?journal=JournalOfBasicAndApplied Suryacitra, G. E. (2018). Efektivitas penerapan model pembelajaran Flipped Classroom di kelas X MIPA SMA Negeri 1 Karanganom tahun Ajaran 2017/2018 pada Materi Vektor.

Varthis, S. (2016). Students' Perceptions of Blended Learning and its Effectiveness As a Part of Second Year Dental Curriculum.

Windi Rahmi Reg, B. (2017). The Effectiveness of Total Physical Response Method In Teaching English Vocabulary To Students With Autism At Sdlb Negeri 027701 Binjai A Thesis.

Xing, B., \& Marwala, T. (2017). Implications of the Fourth Industrial Age on Higher Education. Tạp Chî Nghiên Cúu Dân Tộc. https://doi.org/ 10.25073/0866-773X/87 